\title{
DESKRIPSI PERSONAL HYGIENE PENJAMAH MAKANAN JASABOGA GOLONGAN B PADA PELAKSANAAN EMBARKASI HAJI DI ASRAMA HAJI BEKASI
}

\author{
Fahrul Nur Romadhon ${ }^{1)}$, Mela Firdaust ${ }^{1)}$ \\ 1) Jurusan Kesehatan Lingkungan, Politeknik Kesehatan Kemenkes Semarang
}

\begin{abstract}
Abstrak
Pemeriksaan sanitasi jasaboga asrama haji, meliputi pra embarkasi dan embarkasi. Dari hasil survey pendahuluan, PPIH Asrama Haji telah melaksanakan Inspeksi kesehatan lingkungan asrama haji, terdapat permasalahan pada pemeriksaan usap dubur penjamah makanan yang dilakukan h-3 embarkasi, dan hasil laboratorium baru diketahui setelah 14 hari atau $\mathrm{h}+11$ embarkasi. Tujuan penelitian ini adalah untuk mengetahui gambaran personal hygiene penjamah makanan golongan B pada pelaksanaan embarkasi haji di Asrama haji Bekasi. Jenis penelitian ini adalah deskriptif dengan melakukan pengamatan dan wawancara dengan responden pihak KKP kelas II Bandung, hasilnya diolah dan disajikan dalam bentuk narasi dan tabel kemudian dianalisis dan dibandingkan dengan persyaratan yang ada. Berdasarkan hasil observasi yang dilakukan menggunakan kuesioner dan wawancara daring, tenaga penjamah merupakan tenaga tidak tetap yang hanya mengumpulkan identitas diri, hasil laboratorium usap dubur tenaga penjamah terdapat 25 orang positif salmonella dan shigella hal ini tidak memenuhi persyaratan, Simpulan yang didapat yaitu ketenagaan penjamah makanan tidak memenuhi persyaratan Permenkes 1096 tahun 2011 tentang Higiene Sanitasi Jasaboga. Saran yang dapat diberikan yaitu memberikan masukan kepada pihak jasaboga untuk perekrutan tenaga penjamah menyertakan sertifikat kursus penjamah, dan pemberian tenggang waktu pada pemeriksaan kesehatan apabila ada hasil laboratorium yang tidak, sesuai penjamah makanan dapat diganti.
\end{abstract}

Kata Kunci: Jasaboga; Sanitasi Makanan dan Minuman; Asrama Haji

\begin{abstract}
[Description of Personal Hygiene Foodhandlers Catering Category B in the Implementation of Hajj Embarkation in Bekasi Hajj Dormitory in year of 2019] Hajj boarding sanitation inspection services, including pre-embarkation and embarkation. From the results of the preliminary survey, PPIH Hajj Dormitory has carried out the environmental health inspection of the Hajj hostel, there is a problem in food handkerchief rectal examination done $d-3$ embarkation, and new laboratory results are known after 14 days or $d+11$ embarkations. The aims of this study was to describe the description about personal hygine foodhandlers of Class B food catering in the implementation of Hajj embarkation in Bekasi Hajj Dormitory. This type of research is descriptive by observing and interviewing respondents from the KKP class II Bandung, the results are processed and presented in the form of narratives and tables then analyzed and compared with existing requirements. Based on the results of observations made using online questionnaires and interviews, the requirements were foodhandlers retractors only collect their personal identities, the results of the rectal swab laboratory results of the handlers there 25 positive people of salmonella and shigella, this doesn't meet the requirements. The conclusions obtained were food handlers don't meet the requirements of Permenkes 1096 of 2011 concerning food Catering. Suggestions that can was gave providing input to food catering providers for recruitment of staff including certificate of course, the granting of a period time for a medical examination so that if there were inappropriate laboratory results, foodhandlers can were replaced.
\end{abstract}

Keywords: Catering; Sanitation Food and Drink; Hajj Dormitory 


\section{Pendahuluan}

Penyelenggaraan Kesehatan Lingkungan pada penyelenggaraan kesehatan haji dilaksanakan pada : asrama haji, pesawat; dan katering. Penyelenggaraan Kesehatan Lingkungan pada Asrama Haji dan Katering dilakukan melalui kegiatan: tahap pertama; Inspeksi Kesehatan Lingkungan dilaksanakan pada 6 (enam) bulan sebelum Jemaah Haji masuk asrama haji dan/atau pada saat proses penentuan katering, dengan rekomendasi perbaikan kepada pihak pengelola/penanggung jawab; tahap kedua; Inspeksi Kesehatan Lingkungan dan Intervensi Kesehatan Lingkungan dilaksanakan pada 1 (satu) minggu sebelum jemaah haji masuk Asrama haji, untuk memastikan kesiapan embarkasi jemaah haji. tahap ketiga; dilakukan melalui kegiatan inspeksi Kesehatan Lingkungan dan intervensi Kesehatan Lingkungan secara rutin selama Jemaah haji berada di asrama haji saat embarkasi/debarkasi. Penyelenggaraan kesehatan lingkungan pada Katering dilaksanakan berkoordinasi dengan Kantor Kesehatan Pelabuhan, Balai Teknik Kesehatan Lingkungan, Dinas Kesehatan Kabupaten/Kota, Dinas Kesehatan Provinsi, dan Kementerian Agama. (Kemenkes, 2016)

Pemeriksaan sanitasi jasaboga asrama haji, petugas melakukan pemeriksaan terhadap sanitasi jasaboga peserta lelang, meliputi pemeriksaan administrasi, teknis dan fisik yang dilakukan maksimal 1 bulan sebelum proses embarkasi. Pemeriksaan administrasi dilakukan dengan cara memeriksa kelengkapan administrasi yang harus dipenuhi sesuai dengan Peraturan Menteri Kesehatan RI Nomor 1096/Menkes/Per/VI/2011. Surat rekomendasi diterbitkan oleh Kantor Kesehatan Pelabuhan Kelas II Bandung setelah memenuhi persyaratan administrasi, teknis dan fisik. Setelah ditetapkan pemenang lelang oleh Kemenag, KKP melakukan penyuluhan kepada pemenang tender dan pemeriksaan kesehatan terhadap pengelola dan penjamah makanan dari pemenang lelang jasa boga untuk embarkasi haji. Termasuk usap dubur (rectalswab) yaitu salmonella sp, sigella sp dan vibrio cholera. (Standar Operasional Prosedur KKP Bandung) .

Kantor Kesehatan Pelabuhan mempunyai peranan penting pada penyelengaraan kesehatan haji baik waktu embarkasi maupun debarkasi. Dalam penyelenggaraan kesehatan haji, KKP Kelas II Bandung mempunyai salah satu peran dalam penyelenggaraan kesehatan lingkungan di lingkungan Asrama Haji contohnya Inspeksi Kesehatan Lingkungan dilaksanakan pada 6 (enam) bulan sebelum Jemaah haji masuk Asrama haji dan/atau pada saat proses penentuan katering, dengan rekomendasi perbaikan kepada pihak pengelola/ penanggung jawab, dan penyelenggaraan kesehatan lingkungan pada Jasaboga, Balai Teknik Kesehatan
Lingkungan, Dinas Kesehatan Kabupaten/Kota, Dinas Kesehatan Provinsi, dan Kementerian Agama. Pada waktu peneliti melakukan Studi Pendahuluan / Kerja praktik di KKP Kelas II Bandung, Peneliti dan petugas bidang Pengendalian Resiko Lingkungan KKP Kelas II Bandung telah melaksanakan Inspeksi Kesehatan Lingkungan Asrama Haji, Penyelenggaraan Kesehatan Lingkungan pada Jasaboga meliputi penyuluhan teknis jasaboga di lingkungan asrama haji, cek kesehatan penjamah makanan, hingga usap dubur penjamah makanan. Peneliti telah melaksanakan Pemeriksaan kesehatan penjamah makanan dan Usap dubur, namun pelaksanaan itu baru dimulai $\mathrm{H}-3$ dan belum diketahui hasilnya karena harus menunggu sekitar 2 minggu. Padahal dalam SOP KKP Kelas II Bandung, apabila hasil dari pemeriksaan laboratorium postif membawa penyakit, penjamah makanan itu harus diganti.

Berdasarkan permasalahan tersebut peneliti ingin lebih jauh dan melakukan penelitian yang berjudul "Deskripsi Personal Higiene Penjamah Makanan pada Pelaksanaan Embarkasi Haji di Asrama Haji Bekasi Tahun 2019.

\section{Bahan dan Metode}

Jenis Penelitian ini adalah penelitian deskriptif, dimana peneliti akan mendeskripsikan sifat permasalahan memenuhi persyaratan Permenkes 1096/2011 tentang Higiene Sanitasi Jasaboga dan SOP Sanitasi Lingkungan Asrama Haji KKP Kelas II Bandung atau tidak.

Materi yang disajikan oleh penulis berupa materi penyehatan makanan dan minuman untuk mengetahui data penjamah makanan dengan prinsip hygiene sanitasi makanan dan minuman pada pelaksanaan Embarkasi Haji di Asrama Haji Bekasi. Pengumpulan data yang dilakukan dalam penelitian ini adalah dengan data sekunder yang dimiliki oleh bidang PRL KKP Kelas II Bandung pada penyelenggaran kesehatan lingkungan Asrama Haji Bekasi.

\section{Hasil dan Pembahasan}

\section{A. Data Umum}

Kegiatan Penyelenggaraan Kesehatan Haji Embarkasi Jakarta-Bekasi Tahun 1440 H/ 2019 M periode pemberangkatan (embarkasi) dimulai pada tanggal 8 Juli 2019 sampai dengan 5 Agustus 2019. Asrama Haji Bekasi beralamatkan di Jalan Kemakmuran No 72, Kelurahan Margajaya, Kecamatan Bekasi Selatan, Kota Bekasi, Jawa Barat, 17141. Berdiri pada tanah seluas $30.984 \mathrm{~m}^{2}$ dengan luas bangunan $17.620 \mathrm{~m}^{2}$.

Jasaboga pemenang lelang untuk pengelolaan makanan selama Penyelenggaraan Haji langsung merekrut tenaga kerja tidak tetap sebanyak 75 orang dan hanya mengumpulkan identitas diri berupa Kartu Tanda Penduduk. 


\section{B. Data Khusus}

Karakteristik Penjamah Makanan

1. Data Usia Tenaga Penjamah

Sebanyak 75 tenaga penjamah yang merupakan tenaga tidak tetap memiliki rentang usia dari mulai 15 tahun sampai dengan 56 tahun.

Tabel 4.2 Distribusi frekuensi data penjamah makanan

\begin{tabular}{cc}
\hline $\begin{array}{c}\text { Rentang Usia } \\
\text { Penjamah }\end{array}$ & Frekuensi \\
\hline $15-20$ & 28 \\
\hline $21-26$ & 17 \\
\hline $27-32$ & 7 \\
\hline $33-38$ & 7 \\
\hline $39-44$ & 9 \\
\hline $45-50$ & 3 \\
\hline $51-56$ & 4 \\
\hline Jumlah & 75 \\
\hline
\end{tabular}

Sumber : KKP Kelas II Bandung, 2019

\section{Data Kesehatan Penjamah}

Kesehatan Penjamah Makanan sangat perlu diperhatikan mengingat ruang lingkup higiene sanitasi makanan minuman salah satunya dari penjamah makanan / foodhandler. Berdasarkan observasi yang dilakukan melalui data sekunder yang ada, telah dilaksanakan tes kesehatan penjamah makanan sebelum mereka resmi menjadi tenaga penjamah makanan berupa pemeriksaan tensi tubuh, kebersihan kulit, TBC, dan pemeriksaan usap dubur.

Untuk data kesehatan penjamah makanan melalui pemeriksaan TBC dengan hasil negatif semua, dan apabila positif akan langsung dipulangkan.

Tabel 4.3 Data Pemeriksaan Usap Dubur Penjamah Makanan

Hasil Pemeriksaan Usap Dubur Penjamah Makanan

\begin{tabular}{ccc}
\hline Negatif & $\begin{array}{c}\text { Salmonella } \\
\text { \& Shigella }\end{array}$ & Shigella \\
\hline $\begin{array}{c}\text { 50 tenaga } \\
\text { penjamah }\end{array}$ & $\begin{array}{c}5 \text { tenaga } \\
\text { penjamah }\end{array}$ & $\begin{array}{c}20 \text { tenaga } \\
\text { penjamah }\end{array}$ \\
\hline
\end{tabular}

Sumber : KKP Kelas II Bandung, 2019

Hasil pemeriksaan usap dubur / rectal swab yang keluar setelah kurang lebih 14 hari setelah pemeriksaan atau pada tanggal 18 Juli 2019 (hari ke-11 embarkasi haji) dengan rincian positif shigella sebanyak 20 orang, positif salmonella dan shigella sebanyak 5 orang. Tenaga penjamah yang positif, kemudian tidak diganti melainkan diobati secara intensif selama 5 hari oleh PPIH Asrama haji Bekasi.

Bahwa persyaratan pemeriksaan laboratorium penjamah makanan belum memenuhi persyaratan seperti diatas dan juga perlunya perbaikan pada SOP Sanitasi Lingkungan Asrama Haji (KKP Bandung, 2018) yang hanya memuat melakukan pemeriksaan tanpa ada tenggang waktu tertentu guna mengantisipasi terjadinya KLB keracunan makanan dikarenakan dari penjamah makanan yang positif pembawa kuman patogen.

\section{Upaya Higiene Sanitasi}

Berdasarkan pengalaman empiris langsung peneliti di masa lalu, personal higiene penjamah makanan telah baik seperti yang tercantum dalam Permenkes RI 1096/MENKES/PER/VI/2011 tentang Higiene Sanitasi Jasaboga, antara lain berkuku pendek bersih, tidak berpenyakit kulit, selama bekerja tidak merokok, memakai seragam kerja sesuai dengan bidangnya, tidak memakai perhiasan kecuali cincin kawin, dsb. Namun masih dijumpai penjamah makanan yang masih banyak berbicara, tidak menggunakan penutup rambut, masker, dan sarung tangan secara diam-diam.

Untuk hal-hal yang telah sesuai dengan Standar Operasional Prosedur, perlu dipertahankan secara konsisten dalam upaya menjaga mutu kualitas pangan yang diolah. Untuk hal-hal yang kurang baik, perlu adanya peningkatan dalam beberapa aspek antara lain; misalnya tidak memakai penutup rambut dan atau masker. Upaya tersebut dilakukan untuk meminimalisir kontaminasi yang berasal dari lingkungan dan penjamah makanan sehingga kualitas makanan tetap terjamin mutunya.

\section{Kesimpulan}

a. Syarat Tenaga Penjamah Makanan

Persyaratan penjamah makanan yang bekerja pada jasaboga tersebut masih tidak memenuhi persyaratan sesuai dengan Permenkes No. 1096 Tahun 2011. Sebanyak 75 orang tenaga tidak tetap hanya mengumpulkan identitas diri dan tidak memiliki sertifikat kursus penjamah makanan.

b. Karakteristik Penjamah Makanan

Karakteristik penjamah makanan belum memenuhi persyaratan pada hasil laboratorium Rectal Swab Permenkes 1096 Tahun 2011 tebntang Jasaboga. Hasil laboratorium Rectalswab masih ditemukan total 25 orang penjamah terkonfirmasi positif Shigella dan Salmonella. 


\section{Daftar Pustaka}

Ade Prastomo, 2018, Karya Tulis Ilmiah, Studi Tentang Hygiene Sanitasi Pengelolaan Makanan dan Minuman di Rumah Tahanan Negara Kelas II B Kabupaten Purbalingga Tahun 2018, Poltekkes Semarang Jurusan Kesehatan Lingkungan Purwokerto.

Checklist Laporan Sanitasi Katering Asrama Haji, Kantor Kesehatan Pelabuhan Kelas II Bandung

http://kkpbandung.kemkes.go.id/ diakses pada tanggal 16 April 2020 Pukul 12.30 WIB

http://poltekkes-smg.ac.id/elti/pluginfile.php/130429 Imod resource/content/0/Pengambilan\%20sa mpel\%20rectal\%20swab.pdf diakses pada tanggal 26 November 2019 Pukul 16.02 WIB.

http://www.academia.edu/downloads/

37145779/Praktikum Usap Alat Makan da n_Usap_Dubur_Rectal_Swab.doc diakses pada tanggal 26 November 2019 pukul 15.32 WIB.

http://www.asramahajibekasi.com/about diakses pada tanggal 18 April 2020 pukul 15.15 WIB.

Kemenkes, RI., Peraturan Menteri Kesehatan RI Nomor 62 Tahun 2016 tentang Penyelenggaraan Kesehatan Haji

Kemenkes, RI., Peraturan Menteri Kesehatan RI Nomor 356/MENKES/PER/IV/2008 tentang
Organisasi dan Tata Kerja Kantor Kesehatan Pelabuhan

Kemenkes, RI., Peraturan Menteri Kesehatan RI Nomor 1096 MENKES/PER/VI/2011 tentang Hygiene Sanitasi Jasaboga

Kemenkes, RI., Peraturan Menteri Kesehatan RI Nomor 1098 MENKES/SK/VII/2003 tentang Persyaratan Hygiene Sanitasi Rumah Makan dan Restoran

Laporan Kinerja Tahun 2019, Kantor Kesehatan Pelabuhan Kelas II Bandung

Lutfi Bahtiyar Arif, 2016, Karya Tulis Ilmiah, Studi Personal Hygiene Penjamah Makanan di Instalasi Gizi RSUD Prof. Dr. Margono Soekarjo Purwokerto Kabupaten Banyumas Tahun 2016, Poltekkes Semarang Jurusan Kesehatan Lingkungan Purwokerto.

Profil Kantor Kesehatan Pelabuhan Bandung, 2019

Standar Operasional Prosedur Sanitasi Lingkungan Asrama Haji KKP Kelas II Bandung, 2018

Tri Cahyono, 2020, Panduan Penulisan Tugas Akhir Purwokerto: Kementerian Kesehatan RI Politeknik Kesehatan Semarang Jurusan Kesehatan Lingkungan.

Undang-Undang RI, No. 6 Tahun 2018 tentang Karantina Kesehatan.

Undang-Undang RI, No. 36 Tahun 2009 tentang Kesehatan. 